\title{
Countryside Microfinance - Opportunity for a Sustainable Rural Development
}

\author{
Otilia Manta \\ The School of Advanced Studies of the Romanian Academy Department of Economics, Sociology and \\ Law, Romania \\ otilia.manta@rgic.ro
}

Received date: 25 March 2015; Accepted date: 7 June 2015; Published date: 27 October 2015

Accademic Editor: Andrei lova Radu

Copyright (C) 2015. Otilia Manta. Distributed under Creative Commons CC-BY 4.0

\begin{abstract}
The researcher who assumes the risk of getting an overview of the analysis of the functioning of crediting system in rural areas would have, from the very beginning, some scientific disappointment that our today officials may challenge them. The only aspect, somehow giving hope, is that the system itself works, not for the benefit of the majority of the rural population, but for a few landowners or processors. Theoretically, the rural population's access to bank loans is allowed for all those who want to invest. Basically, the statistics indicate that more than $85 \%$ of the active population in rural areas has no access to rural credit. In most cases, the financing support of rural producers is achieved by European subsidies, rather than by national ones. Saying that, the conclusion is under the circumstances, the only solution for the recovery of the Romanian village is setting up an accessible system for crediting the whole working population. From the perspective of such a goal, the financial and banking support for business in the rural sector is currently the main challenge of the government authorities and, especially, of the financial environment, particularly the banking sector.
\end{abstract}

Key words:rural microfinance, rural credit, sustainable, rural development, economic, social impact.

\section{Introduction}

Microfinancing, as defined in the specialty literature, is the part of the microfinance activities, with reference to the lending activity of small size loans (microcredits) to individuals and/or legal entities in their role as economic actors who are excluded from any traditional financial services (banking).

Based on the concept of "microfinance" and within the context of "Europe 2020, A strategy for smart growth, sustainable and opened to inclusion", we can say that today there is a favorable environment for the creation of economic models of financial support to SME from the Romanian rural area, namely the creation of the microfinance policies. During the approach of this difficult process for financial support, the study tries to emphasize possible new mechanisms for revitalizing the social and economic life of Romanian village. During the reference year of 2015, after two and a half decades of capitalist market economy, in the banking environment from the rural area there is not any specialized lending institution to

Cite this Article as: Otilia Manta (2015), "Countryside Microfinance - Opportunity for a Sustainable Rural Development", Journal of Eastern Europe Research in Business \& Economics, Vol. 2015 (2015), Article ID 460573,

DOI: $10.5171 / 2015.460573$ 
financially support the local community development. An analysis on the subject reveals that the present leverages for support of business environment from the rural area is done through the government financial allocations and just a few bank loans. Only the big companies have acces to these loans. To obtain this kind of loans, the agro farms should prove some solid guarantee. In Romania, the microfinance market is a concept at a starting point. In the general context of sustainable development, to achieve this objective, of the needs of rural microfinance, the implementation of economic models that gives an impulse to align this area to the market economy principles and requirements is essential. The models must be adapted to the concrete and real needs of those who are living and working in rural areas. For this research theme the challenge is both difficult and subject to the risk that some of the advanced ideas may not be in accordance with the current financing policy of decision makers. Beyond these considerations, it is necessary to disclose that to the level of community states, this dynamic market is still quite heterogeneous because of the institutional and legislative disparity and also because of the very diversified microcredit providers. The scientific approach starts from the fact that the Romanian rural area, a total of 2.7 million peasant households, which together account for more than 5 million hectares or 34 percent of the agricultural area of the country, is outside the current system of agricultural financing. There are 2 million added people in rural areas without any plot of land, without a job, who live in extreme poverty. Transferring the european ideas in the Romanian context and correlating them with the statistic economic situation in Romania, I believe that through the creation of economic models of microfinance and in accordance with the current regulatory framework, we can contribute to the sustainable development of this considerable potential that we identified in rural Romania.

\section{A review that calls for reflection}

Microfinancing is not a new reality in Romania. It experienced a particular expanding in the WW1 - WW2 period, when popular banks were institutions that supported the survival of the few entrepreneurs from rural areas, especially the landowners with a certain vocation for the market. The rural banks have the main role in this financing support.

The second category was represented by the craftsmen of villages, which, especially in the WW1 - WW2 period, began to be considered a prosper rural social category. In fact, the rural credit has decisively contributed to the formation of the middle class of peasants.

There are local analysis studies showing that the main element of the rural class progress anchored in the development of the market economy is the Rural Credit. After four and a half decades in which the financial system has been under atypical principles of market economy, in post-revolutionary Romania, the microfinance companies first appeared in 1992, but their contribution to crediting production units or services in rural areas was insignificant. The financial support of the agricultural sector was achieved only through the work of the Rural Credit Guarantee Fund.

The access to the microfinance of the population is a condition for growth of general prosperity. The question we ask is how much of these credits goes to commercial activities? Studies on supply and demand of crediting in rural areas are rare. Microfinance is a viable solution if it combines the efforts of public policy administration, banks, non-bank financial institution (NBFI) and NGOs.

Before addressing a vital problem for the existence and progress of Romanian society, I admit that I put a certain concern. After 25 years of so-called economic and social restructuring, the Romanian village is below the level of poverty bequeathed by the Communists. In rural areas, there are now 5 
million people who suffer from hunger. It is a fact that dramatically distorts the true potential of agriculture, which in rural areas is the main pillar of development. As a potential, Romania is the seventh EU agricultural power. In terms of economic achievements, Romania is in the tail of developed states. Despite such an array of failures, my belief is that, however, as we move forward in time, we foresee some hope on the horizon. After a long strain, caused especially by those who have assumed the responsibility of most sophisticated agrarian reform, in recent years, a relative stability was reached. In lowland areas, the family farms are foreseen to be an essential support in their integration into the market economy. This assessment has a solid explanation, if we consider that the Romanian agriculture vegetable sector, the last two years, has made a real advance, although Romanian farmers have had the lowest financial support from the EU area.

Romania today has a limit of 200 euro / ha and a limit of 0.3 ha. The major objective of the strategy for sustainable development of Romanian agriculture is to ensure food security for the population and the development of availability to help achieve a balance surplus. Is this goal real? Today, we can say yes. The condition is that political and legislative power to offer a real support by deeds and not by promises the agrifood sector by implementing a restructuring program which, according to experts, should contain at least five points.

Unfortunately, the animal husbandry produces the economic imbalances that at a time can put into question the very ability of Romanian agriculture to ensure protein food resource for the population. Most worrying signals coming from the cattle and pig growth. Their contribution in supplying the population drops from year to year. In the decisions of elimination disparities between the two major sectors of the Romanian agriculture, we should proceed from the reality that livestock as a whole is affected by the most dangerous distortion.

\section{The impact of structural adjustment processes and agrarian reform}

Another major objective of a genuine strategy for sustainable development of rural areas is the adjustment of the social and agricultural structures of the Romanian village. It is necessary that the structural adjustment package of laws further facilitates the compatibility of Romanian farms with EU competition farms. What has been achieved so far should be a moment of meditation and analysis for the decision-makers, respectively the politic and executive power, and especially for those who directly manage the destinies of agriculture, of rural areas in general.

Table 1: Romanian agricultural structure, 2012

\begin{tabular}{|l|l|l|l|l|l|}
\hline Felulexploataţiei & Mărimea (ha) & $\begin{array}{l}\text { Număr, } \\
\text { (mii) }\end{array}$ & $\%$ & $\begin{array}{l}\text { Suprafaţa, (mii } \\
\text { ha) }\end{array}$ & \\
\hline 1. Gospodăriinefinanţate & $<1$ & 2.740 & 71,1 & 5.073 & 34,5 \\
\hline $\begin{array}{l}\text { 2. Ferme de subzistențăși } \\
\text { semisubzistență }\end{array}$ & $1-10$ & 1.044 & 27,1 & 3.108 & 21,2 \\
\hline Fermecomerciale, din care & $10-55.000$ & 72 & 1,8 & 6.504 & 44,3 \\
\hline 3. familiale & $10-50$ & $(60)$ & $(1,5)$ & $(1.494)$ & $(10,2)$ \\
\hline 4. societăţi & $100-55.000$ & $(12)$ & $(0,3)$ & $(5.010)$ & $(34,1)$ \\
\hline Total general & $\mathrm{x}$ & 3.856 & 100,0 & 14.685 & 100,0 \\
\hline
\end{tabular}

Source: Acad. Păun Ion Otiman, Romanian agricultural structure, 2012 
Table 2: The Romanian family farm structure

\begin{tabular}{|l|l|l|l|l|l|}
\hline Clasa de mărime a fermei (ha) & Nr. ferme (mii) & $\begin{array}{l}\% \text { din nr. total } \\
\text { ferme }\end{array}$ \\
(mii ha)
\end{tabular} $\begin{aligned} & \text { din total } \\
& \text { Fermefamiliale }\end{aligned}$

Source: Acad. Păun Ion Otiman, The Romanian family farm structure, 2012

Unfortunately, the Romanian village as a whole, both in the condition of the rural economy and in the overall appearance of settlements, seems to stand still in the last 25 years of the communist standards of years 1985 - 1989. At first glance, there may be observed that the research topic of this study would be one of major interest to policy makers who are responsible for substantiating a national strategy for the development of the Romanian rural area.

However, I do mention that rethinking the current system of rural microfinance is an issue that comes to support at least 8 million farmers and the craftsmen who, at the moment, are outside of the concerns of lending and funding. I recognize that not all of them can be connected to the circuit of current market economy. In the villages, there is a large number of people who, through a financial boost, can develop in the short term, sustainable households, including activities to revitalize some old crafts.

\section{Conclusions and considerations}

I confess that personal concerns on issues related to the financial and social inclusion of agricultural units, especially of smallholders, date back from the time when I started developing some investments and support services in rural areas.

Today, for more than $93 \%$ of the rural population, the loans are prohibited.

Faced with this situation, we concluded that the only way to connect Romanian villages to the free market economy circuit is the setting up and the generalization of models or specialized micro companies that can ensure the rural households' access to financial resources, especially through microfinance institutions.It would be, however, noted that Romania has already now clear and concrete measures to support the approximately 830,000 smallholders; there is always plenty to do:

- supporting and revitalization on a small scale farming requires a comprehensive platform for political and development initiatives that are tailored at least to the needs of family farms;

- to keep the long tradition of farming family, friendly policies and regulations are necessary for the environment;

- public investment in rural infrastructure, public services, training and education can provide to small farmers the help they need 
to be competitive in a market increasingly globalized;

- encouraging young farmers to take part in farming will guarantee the long term viability of family farming.

On the European model of nonprofit organizations (in our case, the Business Development Association), directly and indirectly involved in supporting the microfinance/rural microfinance, and through the Romanian Group for Investment and Consulting (RGIC) IFN SA, non-bank financial institution authorized by the National Bank of Romania as microcredit provider, I think we can achieve functional economic models of microfinance for the stakeholders involved in the sustainable development of the Romanian rural area. One of the models is proposed in the present work. Sooner or later, the Romanian financial system will be forced to align with practices of microfinance from countries with developed agriculture. First of all, with those used in European Community countries, but also with those from different regions of the world where agriculture has experienced a spectacular development.

I mean the banking system that functioned with positive results during the boom of the Romanian village. After a period of searching and appealing to some improvisations, I believe that we are at the stage where we are forced to deal with decisions that should lead to the re-establishment, on new principles, of the institutions that provide loans to local actors and vital economic sectors to strengthening communities and welfare. It is about the establishment of banks to finance economic units with legal personality. We talk about banks in rural areas which crediting legal entities and individuals active, banks to finance exclusively educational or health institution from rural area. The capital required to set up such institutions could be provided by government financial contributions for which the costs will be reimbursed. In this action may be involved also the 25 commercial banks operating in
Romania which are involved in lending the food companies. To achieve this goal - the setting up of a national rural microfinance system - it should be started from what was good in the rural credit system in Romania in the interwar period, but especially from existing models today in some countries of the European Union.

\section{References:}

1. Barbulescu, G. (1993) "120 years of Credit for Agriculture Romania",

2. Cârnaru, G. (1915) „Banks Populape, Ideal and Reality" - Critical Economic Study Construction,

3. Caraiani, P. „The effect of credit market frictions on the dynamics of Romanian economy",

Cibian and Oneșteanu,(1930) „Rural credit in light of the interests of agriculture", study National Economy,

4. Dobrescu, E. (2008) „Structural Founds”, Gheorghiu, A. „Risks and vulnerabilities of the lending process",

5. Gusti, D. (1938) „Status Today Romanian village”, Herman, E., Stefanescu, D. „Impact of lending in agriculture lending process”,Herman, E., Stefanescu, D. „An analysis of domestic credit granted for types of institutional sectors",

6. Ionescu, I. (1898) „County, Land Loans Study History, Economic and Legal",

7. Lazar, M. (1944) „Social aspects - agrarian peasant economy (1925-1935),

8. Law on Microfinance Company, (2011) „Communication Committee 2020, A strategy for smart, sustainable and inclusive http://eur-lex.europa.eu

9. Madgearu, V. (1914) „Structure and Trends Popular Banks in Romania", Pelinescu, E. and colab, „Impact of lending policies on the Romanian economy", 
10. Ramirez, J. (2014) European Microfinance Network,

11. Slăvescu, V. (1924) „Appropriation of land in Romania, Publishing",
12. Vulturescu G, (1889)," About Land Credit Societies and their establishment in Romania", 